\title{
PENERAPAN MODEL PEMBELAJARAN MASTER TERHADAP KEMAMPUAN PEMAHAMAN KONSEP SISWA DI SMA N 1 DORO
}

\author{
Dewi Azizah*, Rizka Innayah, Dewi Mardhiyana \\ Pendidikan Matematika FKIP Universitas Pekalongan
}

Korespondensi: azizah.0186@gmail.com

\begin{abstract}
The efforts of teachers to improve students 'ability to understand concepts are to package mathematics learning into learning that can foster students' motivation and passion for learning. The selection of the right learning model by the teacher can make learning effective and fun. One alternative learning model that makes students learn mathematics is fun is the MASTER lesson. This study aims to determine whether students' conceptual comprehension abilities with MASTER learning models are better than PBL learning models. This research is a quantitative research with a form of experimental design that is quasi experimental design .The population in this study were all students of class XI IPS SMA N 1 Doro in the academic year 2017/2018. The data collection methods used in this study are of two kinds, namely interviews and tests. The method of data analysis in this study used the $t$ test. Before the $t$ test, the prerequisite test is first, namely normality and homogeneity test. Based on the calculation of the $t$ test, the results obtained that $t$ value of tcount $=2.133$ and $t 0.025 ; 39=2.023$, so that tcount> t0.025; 39 then Ho is rejected. This means that the MASTER learning model produces a better understanding ability of concepts than the PBL learning model.
\end{abstract}

Keywords: MASTER, PBL, Concept understanding ability

\section{PENDAHULUAN}

Matematika merupakan salah satu bidang studi yang wajib diajarkan pada semua jenjang pendidikan mulai dari pendidikan dasar sampai perguruan tinggi. Matematika memiliki peranan penting dalam dunia pendidikan. Peranan penting tersebut menuntut siswa untuk berpikir logis dan kreatif dalam memecahkan masalah persoalan matematika yang terkait dalam kehidupan sehari-hari. Namun, pada kenyataanya matematika masih dianggap mata pelajaran yang sulit, membosankan dan tak jarang menimbulkan masalah dalam belajar bagi siswa (Marzuki, 2006). Kondisi demikian berakibat pada hasil belajar siswa yang belum memuaskan.

Berdasarkan hasil observasi pembelajaran matematika di SMA N 1 Doro, guru sudah menerapkan model pembelajaran Problem Based Learning (PBL) yang sesuai dengan kurikulum saat ini. Melalui model pembelajaran tersebut, guru dituntut untuk menyajikan permasalahan sebagai dasar belajar siswa. Masalah tersebut merupakan persoalan sehari-hari yang berkaitan dengan materi yang akan dipelajari. Tujuan guru memberikan masalah diawal pembelajaran adalah untuk merangsang siswa berpikir dalam memecahkan persoalan. Harapan guru setelah siswa mampu memecahkan persoalan sendiri adalah siswa mampu mengkonstruksi pengetahuannya sendiri menjadi pengetahuan baru (Syamsurizal, dkk., 2011). Namun, penerapan model PBL di SMA tersebut dikatakan belum sesuai dengan tujuan pembelajaran. Hal ini dilihat ketika siswa dalam memecahkan persoalan secara berkelompok, siswa yang berkemampuan tinggi 
lebih dominan jika dibandingkan dengan siswa yang berkemampuan sedang dan rendah. Berdasarkan gambaran tersebut, tampak bahwa kerjasama antar siswa belum terbentuk dengan baik. Gambaran ini belum sesuai dengan salah satu karakteristik pembelajaran PBL (Abdullah dan Ridwan, 2008). Siswa yang berkemampuan sedang dan rendah cenderung menunggu hasil penyelesaian dari siswa yang berkemampuan tinggi. Akhirnya siswa yang berkemampuan sedang dan rendah pasrah tanpa mau berusaha mencari penyelesaian. Sebenarnya jika semua siswa mau berusaha berpikir untuk memecahkan persoalan tersebut, maka kemampuan pemahaman siswa khususnya kemampuan pemahaman konsep siswa akan terbiasa untuk menyelesaikan persoalan-persoalan matematika. Pentingnya pemahaman konsep tersebut terlihat dalam tujuan pertama pembelajaran matematika menurut Depdiknas (Permendiknas no. 22 tahun 2006) yaitu memahami konsep matematika, menjelaskan keterkaitan antar konsep dan mengaplikasikan konsep atau algoritma secara luwes, akurat, efisien dan tepat dalam pemecahan masalah.

Selain hasil observasi di kelas, hasil wawancara dengan salah satu guru matematika menyatakan bahwa pembelajaran yang didominasi oleh siswa yang berkemampuan tinggi dapat berdampak pada rendahnya kemampuan pemahaman konsep siswa. Hal tersebut dapat dilihat dari hasil ulangan harian 19 siswa pada Materi Statistika. Siswa yang tuntas hanya ada satu anak, sedangkan 18 siswa lainnya tidak tuntas (remedial). Selain itu, berdasarkan analisis hasil ulangan siswa pada Materi Statistika terdapat 50\% siswa belum mampu menyatakan ulang konsep yang telah dipelajari. Hal ini dapat dilihat dari siswa masih melakukan kesalahan dalam menuliskan kembali rumus statistika seperti rumus menentukan persentil pada data kelompok tanpa mencari dulu letak data presentil tersebut dimana. Siswa juga masih bingung dalam mengartikan simbol-simbol yang terdapat dalam rumus matematika, seperti membedakan rumus $d_{1}$ (selisih frekuensi kelas modus dengan kelas sebelumnya) dan ${ }^{d_{2}}$ (selisih frekuensi kelas modus dengan kelas setelahnya), cara menetukan frekuensi komulatif kurang dari dan lebih dari, dan lain-lain. Beberapa siswa juga masih lemah dalam mengelompokkan objek berdasarkan konsep matematika yang telah dipelajari. Selain itu, siswa menjawab soal dengan langsung menuliskan hasil akhir tanpa menentukan unsur-unsur yang diperlukan untuk proses perhitungannya. Hal ini menunjukkan bahwa siswa belum mampu menerapkan konsep secara urut. Menurut Jihad (2012) salah satu kecakapan dan kemahiran yang diharapkan dalam menyelesaikan persoalan matematika adalah kemampuan pemahaman konsep siswa. Pemahaman konsep merupakan salah satu kompetensi siswa dalam memahami konsep secara luwes, akurat, efisien dan tepat. Siswa yang menguasai konsep dapat dengan mudah mengidentifikasi dan menyelesaikan persoalan-persoalan matematika. Hal ini sesuai dengan pendapat Hamalik dalam Andriani, dkk., (2016) bahwa siswa yang menguasai konsep matematika dengan baik, maka siswa akan mudah dalam menyelesaikan persoalan-persoalan matematika. Oleh karena itu, upaya untuk meningkatkan kemampuan pemahaman konsep siswa adalah dengan mengemas pembelajaran matematika menjadi pembelajaran yang dapat menumbuhkan motivasi dan gairah siswa untuk belajar.

Salah satu alternatif model pembelajaran yang membuat siswa belajar matematika itu menyenangkan dan efektif adalah Accelerated Learning. Salah satu model pembelajaran yang memungkinkan siswa dapat belajar secara alamiah sehingga membuat 
siswa merasa bahwa belajar itu menyenangkan, efektif, dan cepat (Yuniati, 2012). Model pembelajaran MASTER merupakan suatu langkah dalam Cara Belajar Cepat (CBC) yang dapat mempermudah siswa dalam memahami konsep dengan cepat dan baik. Menurut Trianto (2007) dalam mengajarkan materi tertentu harus dipilih model pembelajaran yang paling sesuai dengan tujuan yang akan dicapai. Pembelajaran akan efektif jika guru tepat dalam memilih model pembelajaran. Penelitian ini bertujuan untuk mengetahui apakah kemampuan pemahaman konsep siswa dengan model pembelajaran MASTER lebih baik daripada model pembelajaran PBL.

\section{KAJIAN TEORI}

\subsection{Model Pembelajaran MASTER}

Menurut Rose dan Nicholl (2002), Accelerated Learning atau Cara Belajar Cepat (CBC) dibagi menjadi enam langkah dasar. Keenam langkah tersebut disingkat dengan istilah MASTER, yaitu: (1) Motivating Your Mind (Memotivasi Pikiran Anda), siswa harus dalam keadaan relaks, percaya diri, dan termotivasi dalam belajar. (2) Acquiring The Information (Memperoleh Informasi), dalam belajar siswa harus memperoleh dan menyerap fakta-fakta dasar dari suatu materi. (3) Searching Out the Meaning (Menyelidiki Makna), siswa berdiskusi secara berkelompok untuk menyelidiki makna yang terdapat pada materi yang baru saja diperoleh. (4) Triggering The Memory (Memicu Memori), siswa diberikan pertanyaan seputar materi yang baru dipelajari. Hal ini bertujuan untuk memicu memori serta pemahaman siswa. (5) Exhibiting What You Know (Memamerkan Apa Yang Anda Ketahui), siswa mempersentasikan hasil diskusi kelompok kepada siswa lainnya. (6) Reflecting How You've Learned (Merefleksikan Bagaimana Anda Belajar), siswa bersama guru merefleksikan materi yang telah dipelajari dan bagaimana proses pembelajaran itu dilakukan.

Menurut Tanjung (2015) langkah-langkah model pembelajaran MASTER sebagai berikut.

1. Mind

Guru memberikan stimulus untuk siswa melalui video pembelajaran yang berisi materi yang akan dipelajari. Tujuan dari video pembelajaran tersebut agar siswa dapat merelaksasi pikiran dan menjelaskan manfaat dari materi yang akan dipelajari.

2. Acquire

Guru menjelaskan materi yang akan dipelajari dan siswa memperoleh informasi dari penjelasan tersebut. Guru memberikan permasalahan matematika untuk merangsang berpikir siswa. Ketika siswa mengalami kesulitan, guru membantu membimbing siswa.

3. Search out

siswa diberi kesempatan untuk berdiskusi kelompok agar materi yang dipelajari bermakna. Siswa dituntut lebih aktif dan kreatif dalam memaknai konsep yang diperoleh sehingga siswa mudah dan terbiasa dalam menyelesaikan permasalahanpermasalahan yang diberikan guru.

4. Trigger

Guru melatih kerja otak siswa dalam menyimpan dan mengingat materi yang telah dipelajari melalui proses pengulangan materi. 


\section{Exhibit}

Siswa diberi kesempatan mempresentasikan hasil kerja kelompoknya di depan kelompok lain untuk menguji sejauh mana pemahamannya.

6. Reflect

Guru bersama siswa mengevaluasi terhadap kelebihan dan kekurangan dari kegiatan pembelajaran yang telah dilakukan di kelas. Kemudian guru memberikan kuis kepada siswa yang dikerjakan secara individu.

Penerapan enam langkah tersebut dalam pembelajaran di kelas dapat membantu siswa dalam memahami konsep materi, siswa terbiasa menganalisa permasalahan- permasalahan matematika, siswa dapat berlatih berpikir dengan cepat, dan pembelajaran di kelas lebih bermakna dan menyenangkan.

\subsection{Kemampuan Pemahaman Konsep Matematika}

Menurut Kilpatrick (dalam Lestari dan Yudhanegara, 2015), kemampuan pemahaman konsep matematika adalah kemampuan yang berkenaan dengan memahami ide-ide matematika yang menyeluruh dan fungsional. Indikator kemampuan pemahaman konsep yang menjadi fokus dalam penelitian ini meliputi menyatakan ulang sebuah konsep, mengklasifikasikan objek-objek berdasarkan konsep matematika, dan menerapkan konsep secara urut (algoritma). Ketiga indikator tersebut diperoleh berdasarkan hasil wawancara dengan guru matematika. Hasil wawancara menyatakan bahwa siswa masih bingung dalam menjelaskan konsep syarat fungsi yang dapat dikomposisikan. Sebagian besar siswa juga masih belum bisa mencari domain dan range suatu fungsi. Pada saat siswa menyelesaikan soal terkait invers fungsi komposisi, siswa masih bingung dalam menentukan langkah yang harus dikerjakan, karena pemahaman siswa terkait materi tersebut masih kurang.

\section{METODE PENELITIAN}

Penelitian ini merupakan penelitian kuantitatif dengan bentuk desain eksperimen yaitu quasi experimental design. Adapun design penelitian yang digunakan dalam penelitian ini adalah the nonequivalent posttest-only control group design. Perlakuan yang diberikan kepada kelas eksperimen adalah penerapan model pembelajaran MASTER, sedangkan kelas kontrol diberi perlakuan menggunakan model pembelajaran PBL. Populasi dalam penelitian ini adalah seluruh siswa kelas XI IPS SMA N 1 Doro tahun ajaran 2017/2018 yang terdiri dari tiga kelas yaitu kelas XI IPS 1, XI IPS 2, dan XI IPS 3. Teknik pengambilan sampel yang digunakan berdasarkan teknik cluster random sampling. Cluster random sampling yang dimaksud dalam penelitian ini adalah acak kelas, yaitu dari tiga kelas yang ada akan dipilih 2 kelas secara acak. Kelas yang terpilih akan menjadi kelas sampel, yaitu sebagai kelas eksperimen dan kelas kontrol. Berdasarkan acak kelas tersebut, sampel yang terpilih yaitu kelas XI IPS 2 sebagai kelas eksperimen, dan kelas XI IPS 3 sebagai kelas kontrol.

Metode pengumpulan data yang digunakan dalam penelitian ini ada dua macam yaitu wawancara dan tes. Pada penelitian ini, wawancara dilakukan untuk memperoleh informasi terkait permasalahan yang terjadi pada saat pembelajaran matematika, yang meliputi aspek kognitif (kemampuan pemahaman konsep). Wawancara juga dilakukan untuk memperoleh informasi terkait model pembelajaran yang biasa digunakan oleh guru. 
Adapun instrumen tes yang dibuat dalam penelitian ini berupa soal essay yang terdiri dari 10 butir soal tentang materi Fungsi Komposisi. Instrumen tes yang digunakan harus memenuhi syarat-syarat butir instrumen. Untuk mengetahui bahwa instrumen yang disusun telah memenuhi syarat maka perlu dilakukan perhitungan validitas isi, daya beda, tingkat kesukaran dan reliabilitas. Berdasarkan hasil analisis uji coba tes kemampuan pemahaman konsep, diperoleh enam soal yang memenuhi kriteria kelayakan soal dari sepuluh soal yang diujicobakan. Enam soal tersebut digunakan untuk mengukur kemampuan pemahaman konsep siswa pada kelas eksperimen dan kelas kontrol. Metode analisis data pada penelitian ini menggunakan uji t. Sebelum uji t, terlebih dahulu dilakukan uji prasyarat yaitu normalitas dan uji homogenitas.

\section{HASIL DAN PEMBAHASAN}

Penelitian eksperimen ini diawali dengan melakukan uji keseimbangan sampel menggunakan uji t. Uji keseimbangan digunakan untuk mengetahui sampel berasal dari populasi yang memiliki kondisi awal yang sama atau tidak. Berdasarkan perhitungan uji t, dapat disimpulkan bahwa kemampuan awal antar kelas eksperimen dan kontrol sama.

Pada kelas XI IPS 2 sebagai kelas eksperimen diberi perlakuan model pembelajaran MASTER dan kelas XI IPS 3 sebagai kelas kontrol diberi perlakuan model pembelajaran PBL. Setelah diberi masing-masing kelas diberikan perlakuan, kedua kelas tersebut diberikan tes kemampuan pemahaman konsep. Berikut ini hasil tes kemampuan pemahaman konsep siswa.

Tabel 1 Data Kemampuan Pemahaman Konsep

\begin{tabular}{ccc}
\hline Statistik Deskripsi & Kelas Eksperimen & Kelas Kontrol \\
\hline Jumlah $(\mathrm{n})$ & 21 & 20 \\
Nilai Tertinggi & 86 & 83 \\
Nilai Terendah & 58 & 47 \\
Rata-rata & 71 & 64,70 \\
Varians $\left(\mathrm{s}^{2}\right)$ & 64,70 & 115,38 \\
Simpangan Baku (s) & 8,04 & 10,74 \\
\hline
\end{tabular}

Sebelum melakukan uji hipotesis, terlebih dahulu dilakukan uji prasyarat yaitu uji normalitas dan uji homogenitas. Uji normalitas menggunakan metode Liliefors dengan taraf signifikasi 5\%. Setelah perhitungan, diperoleh untuk masing-masing kelompok sampel baik kelas MASTER maupun PBL berasal dari populasi yang berdistribusi normal. Setelah uji normalitas terpenuhi, selanjutnya dilakukan uji homogenitas. Uji homogenitas menggunakan uji $\mathrm{F}$ dengan taraf signifikasi 5\%. Setelah perhitungan, diperoleh bahwa sampel berasal dari populasi yang homogen.

Pada penelitian ini uji hipotesis menggunakan uji perbedaan rerata (uji t). Uji ini dilakukan untuk mengetahui apakah model pembelajaran MASTER menghasilkan kemampuan pemahaman konsep yang lebih baik daripada model pembelajaran PBL. Berdasarkan perhitungan uji $\mathrm{t}$, diperoleh $\mathrm{t}_{\text {hitung }}=2,133$ dan $\mathrm{t}_{0,025 ; 39}=2,023$, sehingga $\mathrm{t}_{\text {hitung }}$ $>\mathrm{t}_{0,025 ; 39}$ maka $\mathrm{H}_{0}$ ditolak. Artinya bahwa model pembelajaran MASTER menghasilkan kemampuan pemahaman konsep yang lebih baik daripada model pembelajaran PBL. Hal ini sesuai penelitian yang dilakukan oleh Tanjung (2015), menyatakan bahwa nilai postes pada kelas dengan model pembelajaran MASTER lebih baik daripada nilai postes kelas 
dengan model pembelajaran konvensional. Senada juga dengan penelitian yang dilakukan oleh Shoum (2014), menyatakan bahwa hasil belajar pada kelas eksperimen dengan model pembelajaran MASTER lebih baik daripada hasil belajar kelas kontrol dengan model pembelajaran biasa yang diterapkan oleh guru.

Penerapan model pembelajaran MASTER dapat menumbuhkan motivasi belajar siswa sehingga kemampuan pemahaman konsep siswa menjadi lebih baik. Langkahlangkah model pembelajaran MASTER yang telah telaksanakan yaitu pada tahap mind, dimana pada tahap tersebut guru menampilkan video pembelajaran yang bertujuan untuk menciptakan lingkungan belajar yang menyenangkan. Video pembelajaran tersebut berisi materi dan latihan-latihan soal yang sewaktu-waktu bisa digunakan belajar siswa di rumah. Guru menyusun video ini sebagai salah satu inovasi dalam pembelajaran. Melalui video pembelajaran, minat belajar matematika siswa dapat meningkat. Pada tahap acquire, penyampaian materi yang diberikan guru diawal pembelajaran juga membantu siswa dalam mengkonstruksikan konsep dan menyelesaikan permasalahan matematika baik secara kelompok maupun individu. Pada tahap search out, siswa melalui diskusi kelompok dapat bertukar pikiran dalam menemukan konsep materi fungsi komposisi sehingga dapat mempermudah dalam menyelesaikan permasalahan matematika. Dalam berkelompok, kerjasama antar siswa dapat terlaksana dengan baik. Siswa yang berkemampuan tinggi tidak merasa egois dapat menyelesaikan persoalan sendiri. Namun, siswa yg berkemampuan tinggi justru membimbing siswa yang lain yang belum paham. Pada tahap trigger, siswa juga melakukan pengulangan materi. Hal ini bertujuan agar siswa lebih mudah mengingat konsep materi ke dalam memori dalam jangka panjang. Hal ini sesuai dengan teori Ausubel yang mengatakan bahwa pentingnya pengulangan materi sebelum pelajaran dimulai sehingga belajar menjadi lebih bermakna bagi siswa (Suherman, dkk., 2003). Jika siswa dibiasakan melakukan pengulangan materi maka siswa akan lebih mudah memahami konsep materi tanpa harus menghafalkannya. Selain itu, siswa lebih mudah dalam mengaitkan pengetahuan baru yang diperolehnya dengan pengetahuan sebelumnya yang relevan. Pada tahap exhibit, siswa diberi kesempatan untuk memaparkan hasil diskusinya di papan tulis. Pada tahap reflect, siswa dan guru mengevaluasi pembelajaran yang telah dilaksanakan. Penerapan model pembelajaran Master dapat terlaksana dengan baik sesuai dengan tujuan pembelajaran yaitu untuk menumbuhkan kemampuan pemahaman konsep matematika siswa.

\section{SIMPULAN DAN SARAN}

Berdasarkan hasil penelitian dan pembahasan yang telah diuraikan, diperoleh simpulan bahwa kemampuan pemahaman konsep siswa dengan model pembelajaran MASTER lebih baik daripada model pembelajaran PBL. Saran yang diberikan yaitu: (1) model pembelajaran MASTER dapat digunakan sebagai salah satu referensi model pembelajaran di kelas oleh guru-guru di Kota Pekalongan dengan materi yang berbeda, (2) model pembelajaran MASTER dapat digunakan untuk mengukur kemampuan kognitif siswa di Kota Pekalongan selain kemampuan pemahaman konsep. 


\section{DAFTAR PUSTAKA}

Abdullah, A. G dan Ridwan, T., 2008. Implementasi Problem Based Learning pada Proses Pembelajaran di BPTP Bandung. Prosiding UPI : 1-10.

Andriani, Eka, dkk., 2016. Peningkatan Kompetensi Pedagogik Guru Dan Kemampuan Akademik Siswa Melalui Lesson Study. Jurnal Pendidikan: Teori, Penelitian dan Pengembangan, 1(1), 2106-2112.

Depdiknas. 2006. Permendiknas No 22 Tahun 2006 Tentang Standar Isi. Jakarta: Depdiknas.

J. Nicholl, Malcolm dan Collin Rose. 2002. Cara Belajar Cepat Abad XXI. Edisike 3. Diterjemahkan oleh Ahimsa. Bandung: Nuansa Cendekia.

Jihad, Asep \& Abdul Haris. 2012. Evaluasi Pembelajaran. Yogyakarta: Multi Presindo.

Lestari, Karunia Eka dan Mokhammad Ridwan Yudhanegara. 2015. Penelitian Pendidikan Matematika. Bandung: PT Refika Aditama.

Marzuki, 2006. Evaluasi Pembelajaran. Jakarta: Kencana Perdana Media Group.

Tanjung, Yul Ifda. 2015. Pengaruh Konsep Accelerated Teaching Model MASTER terhadap Hasil Belajar Fisika Siswa. Jurnal Ikatan Alumni Fisika Universitas Negeri Medan. $1(1), 50-54$.

Shoum, Risalatul Lutfiyah, Sri Astutik, Rif'ati Dina Handayani. 2014. Metode Eksperimen dengan Teknik MASTER pada Pembelajaran Fisika di SMP. Jurnal Pembelajaran Fisika.

Syamsurizal, Rusdi, M dan Sastrawati, E., 2011. Problem Based Learning, Strategi Metakognisi, dan Ketrampilan Berpikir Tingkat Tinggi Siswa. Jurnal TeknoPedagogi, 1(1), 1-14.

Suherman, Erman, Turmudi, Didi Suryadi, Tatang Herman, Suhendra, Sufyani Prabawanto, Nurjanah, Ade Rohayati. 2003. Strategi Pembelajaran Matematika Kontemporer. Bandung: Universitas Pendidikan Indonesia.

Trianto. 2007. Model-model Pembelajaran Inovatif Berorientasi Konstruktivisme. Jakarta : Prestasi Pustaka.

Yuniati, Suci. 2012. Pembelajaran dengan Metode Accelerated Learning pada Materi Keliling dan Luas Lingkaran. Beta. 5(1): 57-74. 